\title{
Increases in plasma levels of atrial and brain natriuretic peptides after running a marathon: are their effects partly counterbalanced by adrenocortical steroids?
}

\author{
Alexander Niessner, Sophie Ziegler ${ }^{1}$, Jörg Slany ${ }^{2}$, Elke Billensteiner ${ }^{3}$, Wolfgang Woloszczuk ${ }^{4}$ and Georg Geyer ${ }^{4}$ \\ Division of Cardiology and ${ }^{1}$ Division of Angiology, Department of Internal Medicine II, General University Hospital, Waehringer Guertel 18-20, \\ A-1090 Vienna, Austria, ${ }^{2}$ Department of Internal Medicine II, Hospital Rudolfstiftung, Juchgasse 25, A-1030 Vienna, Austria, ${ }^{3}$ Institute of Medical \\ Statistics, University of Vienna, Schwarzspanierstraße 17, A-1090 Vienna, Austria, and ${ }^{4}$ Ludwig Boltzmann Institut für Experimentelle Endokrinologie, \\ Waehringer Guertel 18-20, A-1090 Vienna, Austria \\ (Correspondence should be addressed to A Niessner; Email: alexander.niessner@univie.ac.at)
}

\begin{abstract}
Objective: Long-distance running results in considerable stress. Little evidence exists about the role of the atrial and brain natriuretic peptides, ANP and BNP, deriving from the myocardium. The aim of our study was to investigate the influence of running $42.195 \mathrm{~km}$ on changes in circulating natriuretic propeptides and adrenocortical steroids.

Design and methods: We studied 17 male and 2 female runners (age: 28-62 years) participating in a marathon. Blood samples were obtained before and immediately after the competition. proANP(1-98) and proANP(1-30) as well as Nt-proBNP(8-29) were determined by enzyme immunoassays.

Results: Runners finished the competition between $2 \mathrm{~h} 58 \mathrm{~min}$ and $4 \mathrm{~h} 25 \mathrm{~min}$. We observed a more pronounced increase in proANP $(1-98)(+58 \%)$ and proANP $(1-30)(+99 \%$, both $P<0.001)$ compared with Nt-proBNP $(8-29)(+6 \% ; P=0.005)$. Increases in proANP $(1-30)$ positively correlated with runners' age $(r=0.53 ; P=0.02)$. We also observed a marked increase in cortisol $(+73 \%)$ and especially in aldosterone $(+431 \%$, both $P<0.001)$.

Conclusions: Cardiac strain during long-distance running may explain the pronounced increase in proANP. Other explanations for the observed rise in plasma levels might be a change in the permeability of myocardial cells and an impaired clearance. A rise in adrenocortical steroids may compensate for the negative influence of ANP on natriuresis and blood pressure. Positive effects of ANP during a marathon could be the regulation of body temperature by influencing sweat glands as well as the stimulation of lipolysis compensating for the enormous energy demand.
\end{abstract}

European Journal of Endocrinology 149 555-559

\section{Introduction}

Running the marathon distance of $42.195 \mathrm{~km}$ results in considerable physical and mental stress. Selye (1950) described the important influence of endocrine regulations in response to such a condition (1). The activation by endurance running up-regulates circulating catecholamines $(2-4)$ and stimulates the "classic hormones of adaptation' corticotropin releasing hormone-adrenocorticotropin-cortisol (2, 5-7). Somatotropic hormone $(8)$ as well as leptin $(9,10)$ are responsible for the provision of energy, which is critical for running such a long distance. There are still few data about a response of atrial natriuretic peptide (ANP) (11) and brain natriuretic peptide (BNP) $(12,13)$ during a marathon. Deriving predominantly from myocardial cells due to elevated strain they increase natriuresis $(14,15)$. In addition, ANP seems to reduce systemic blood pressure (16-18). The aim of our study was to investigate the change in natriuretic peptides in response to running a marathon by determining their circulating precursors. Moreover, we investigated their interaction with adrenocortical steroids in the regulation of circulation and body fluids.

\section{Subjects and methods}

We studied 17 male and two female runners competing in a marathon in Maranello (Italy). Their ages ranged from 28 to 62 years. Demographic data are presented in Table 1. The runners finished the race between $2 \mathrm{~h}$ $58 \mathrm{~min}$ and $4 \mathrm{~h} 25 \mathrm{~min}$ indicating their state of fitness. Temperatures were fairly warm being $24^{\circ} \mathrm{C}$ in the morning. During the race athletes were encouraged to drink sufficient amounts of an isotonic dextrose/ electrolyte solution, which was offered every $5 \mathrm{~km}$. 
Table 1 Demographic data. Results are expressed as means \pm S.D.

\begin{tabular}{lc}
\hline Age (years) & $44.7 \pm 9.2$ \\
Gender (F/M) & $2 / 17$ \\
Marathon (h:min) & $03: 42 \pm 00: 41$ \\
\hline
\end{tabular}

No one needed medical assistance during the marathon or afterwards.

Venous blood samples were obtained before the start and immediately after finishing the marathon. The native venous blood was stored without anticoagulant and transported to the laboratory in Vienna by plane at room temperature. Only then were the sera centrifuged and stored at $-40{ }^{\circ} \mathrm{C}$ until analyses. This lack of cooling during transportation did not allow all desirable determinations because of the known instability of certain parameters.

Fractions $1-30$ and $1-98$ of proANP as well as the N-terminal fraction 8-29 of proBNP were determined by commercially available enzyme immunoassays (Biomedica, Vienna, Austria). As indicated by the manufacturer, respective reference ranges $(5$ th -95 th percentiles) were $0.11-0.47 \mathrm{nmol} / \mathrm{l}$ for $\operatorname{proANP}(1-30)$, $<1.95 \mathrm{nmol} / \mathrm{l}$ for proANP(1-98) and $<0.25 \mathrm{nmol} / \mathrm{l}$ for Nt-proBNP(8-29). We used commercial kits for the determination of cortisol and aldosterone (Immunotech, Marseille, France). Troponin-I and creatine kinase-MB (CK-MB)-mass were determined using standardized methods as previously described (19).

Data are given as median (interquartile range) if not stated otherwise. The Wilcoxon signed rank test was used to test for differences in serum levels of hormones before and after the competition. Spearman's correlation coefficient was calculated for changes in serum levels of the determined hormones, troponin-I and CK-MB-mass as well as for individual age and running time. A value of $P<0.05$ (2-tailed) was considered statistically significant. The SAS statistical program was used for data analysis (SAS Istitute Inc., Cary, NC, USA).

\section{Results}

All fractions of natriuretic propeptides were significantly increased after running the marathon compared with basal levels (Table 2). We observed a pronounced rise in proANP $(1-98)(+58 \%)$ and proANP $(1-30)$ $(+99 \%)$ (Table 2 and Fig. $1, P<0.0001)$. Increases in proANP $(1-30)$ but not in proANP $(1-98)$ positively correlated with the age of the runners $(r=0.53$, $P=0.02)$. Furthermore, there was a trend towards a positive correlation for changes in proANP(1-30) with troponin-I $(r=0.44, \quad P=0.06)$ and CK-MBmass $(r=0.44, P=0.08)$.

Nt-proBNP(8-29) also increased significantly during the marathon but more moderately $(+6 \%)$ compared with fractions of proANP (Table 2 and Fig. 1, $P=0.005)$. Changes in Nt-proBNP(8-29) showed a positive and almost significant correlation with runners' age $(r=0.44, P=0.06)$. There was no association with CK-MB-mass or troponin-I. Increases in natriuretic propeptides did not correlate with the individual running time.

Plasma levels of adrenocortical steroids also increased significantly. Aldosterone showed a 4.3-fold increase from $0.17(0.14-0.23) \mathrm{nmol} / \mathrm{l}$ to $0.69(0.52-1.39)$ nmol/l (Table 2 and Fig. 1, $P<0.0001)$. Plasma levels of cortisol rose by $73 \%(P<0.0001)$. Increases in aldosterone and cortisol were positively correlated $(r=0.71, P=0.001)$. They were not associated with individual age and running time or with CK-MB-mass and troponin-I.

\section{Discussion}

Our results demonstrate a significant increase in fractions of the myocardial prohormones proANP and proBNP in blood samples of well-trained healthy runners after a marathon. The Nt-proBNP $(8-29)$ fraction rose considerably less than the fractions of proANP. These results correspond to data obtained after acute exercise showing a low BNP/ANP ratio in healthy subjects (20). The higher BNP/ANP ratio after an ultramarathon of $100 \mathrm{~km}$ in healthy individuals observed by Ohba et al. (21) indicates a distance-dependent influence.

Myocardial stretch due to an increase in atrial dimensions is the main stimulus for an increased ANP release at rest $(22,23)$. During acute exercise an increase in atrial distension $(24,25)$ probably due to increased central blood volume (26) and a corresponding rise in

Table 2 Serum levels of natriuretic propetides and corticosteroids before and after running a marathon. Results are expressed as median (interquartile range).

\begin{tabular}{|c|c|c|c|}
\hline & Before marathon & After marathon & $\boldsymbol{P}^{*}$ \\
\hline $\operatorname{proANP}(1-98)(\mathrm{nmol} / \mathrm{l})$ & $2.19(1.47-2.90)$ & $3.88(2.63-4.80)$ & $<0.0001$ \\
\hline $\operatorname{proANP}(1-30)(\mathrm{nmol} / \mathrm{l})$ & $0.78(0.60-0.97)$ & $1.58(1.10-2.46)$ & $<0.0001$ \\
\hline Nt-proBNP $(8-29)(\mathrm{nmol} / \mathrm{l})$ & $0.18(0.15-0.21)$ & $0.19(0.18-0.25)$ & 0.0052 \\
\hline Cortisol $(\mathrm{nmol} / \mathrm{l})$ & $622.0(543.0-683.0)$ & $897.0(730.0-1249.0)$ & $<0.0001$ \\
\hline Aldosterone (nmol/l) & $0.166(0.136-0.227)$ & $0.693(0.515-1.385)^{\prime}$ & $<0.0001$ \\
\hline
\end{tabular}

*Wilcoxon signed rank test. 


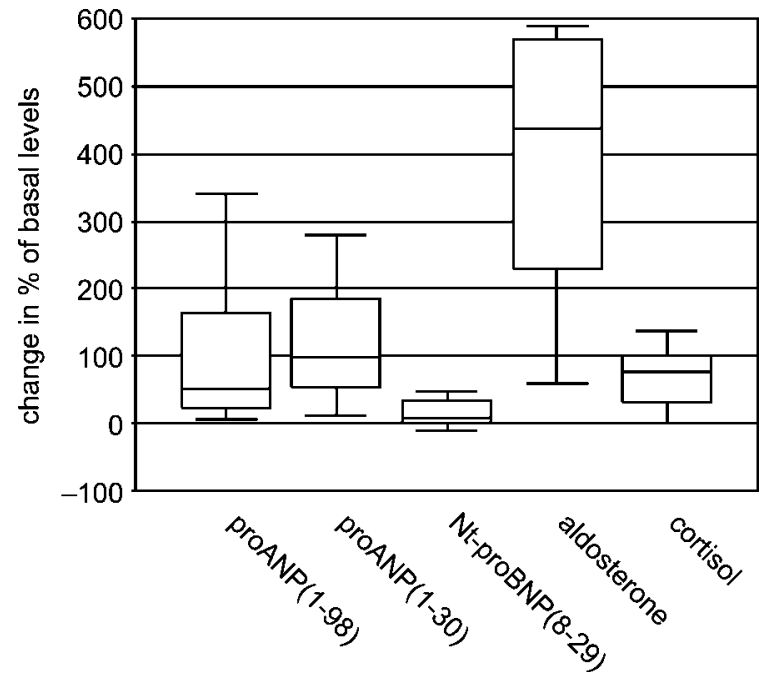

Figure 1 Changes in natriuretic propeptides and adrenocortical steroids after running a marathon. proANP $(1-98)$ and proANP $(1-30)=$ fractions $1-98$ and $1-30$ of proANP. Nt-proBNP $(8-29)=\mathrm{N}$-terminal fraction $8-29$ of proBNP. Boxplots show median (line), interquartile range (box) and values within 3 interquartile ranges (whiskers) excluding the following outliers: Nt-proBNP(8-29) $+108 \%$, aldosterone $+1955 \%$ and cortisol $+239 \%$.

atrial pressure $(27,28)$ have been associated with an increase in ANP in healthy individuals. However, during prolonged strenuous exercise, atrial size (29) and pressure $(30,31)$ decrease. The influence of other hormones $(4,32,33)$ or a rise in the heart rate $(32$, 34) could increase secretion of ANP under these circumstances.

On the other hand, less elevated plasma levels of ANP after prolonged exercise compared with acute exercise (34, 35) might reflect impaired clearance of initially secreted ANP because of a decreased blood flow in internal organs such as the kidneys (36). But we think that a significantly decreased clearance of natriuretic peptides during the marathon would have altered plasma levels of BNP to a greater extent because of its delayed clearance (23).

Additionally, a partial correlation of ANP and troponin release $(19,21)$ could indicate a transient pathological process of simultaneous release from myocardial cells due to exercise. A change in cellular permeability by means of oxidative stress (37) and subsequent leakage of proteins might explain this phenomenon, although ANP and troponin derive from different compartments of the myocardial cell. We conclude that the origin of prominently elevated plasma levels of ANP after prolonged exercise includes various stimuli for secretion and probably to a minor extent impaired clearance as well as pathological leakage.

Different factors may influence the individual rise in ANP after prolonged exercise. The observed correlation of increases in proANP $(1-30)$ with the individual age of the runners confirms data about an exaggerated release of ANP in older individuals $(34,38,39)$. A polymorphism of the angiotensin-converting enzyme may also influence the release of ANP (40). Furthermore, hot environmental temperatures result in decreased secretion of ANP (41-45), while progressive rehydration preventing a decrease in body fluids causes a more pronounced increase in ANP (44). We assume that an ample supply of isotonic drinks during the marathon together with the fairly warm environmental temperatures (46) resulted in a moderate body fluid loss in our study population.

What is the purpose of the observed prominent increase in ANP during prolonged exercise? Electrolyte loss and reduced blood pressure caused by ANP can hardly be expected to improve the hemodynamic stability of a runner. Adrenocortical steroids may counterbalance these negative effects, decreasing urinary fractional excretion of sodium (47). Prolonged exercise, such as competing in a marathon, even causes antidiuresis (48) probably due to the marked increase in adrenocortical steroids $(2,11,49-51)$ concomitantly with sympathoadrenal activation (52).

However, ANP may influence fluid regulation by shifting fluid from the intra- to the extravascular space (53). Receptors for natriuretic peptides in human sweat glands (54) might indicate a meaningful role for these peptides in the regulation of core temperature. A clearly positive and specific effect of ANP during prolonged exercise could be a potent stimulation of lipolysis in adipose tissue (55-57). Thus ANP may help to compensate the immense and limiting energy demand during long-distance running by elevating circulating free fatty acids (58).

\section{Acknowledgements}

The authors would like to express their thanks to Dr Edda Slany who provided the logistic management for the study in Maranello. Furthermore, we are grateful to Mrs Annemaria Raffetseder for her expert technical assistance. The support of the Austrian runners' group by Takeda-Austria, Pharmaceutical Company, is gratefully acknowledged. Finally, we would like to thank the anonymous reviewers for their helpful comments for improving the discussion.

\section{References}

1 Selye H. In Stress. The Physiology and Pathology of Exposure to Stress. Montreal: Acta Inc. Medical Publishers, 1950.

2 Franz KB, Ruddel H, Todd GL, Dorheim TA, Buell JC \& Eliot RS. Physiologic changes during a marathon, with special reference to magnesium. Journal of the American College of Nutrition 1985 4 187-194.

3 Schultz KD, Fritschka E, Kribben A, Rothschild M, Thiede HM, Distler A et al. Alpha 2- and beta 2-adrenoceptor downregulation in marathon runners. Journal of Hypertension 19897 S48-S49. 
4 Tanaka H, Cleroux J, de-Champlain J, Ducharme JR \& Collu R. Persistent effects of a marathon run on the pituitary-testicular axis. Journal of Endocrinological Investigation $1986997-101$.

5 Heitkamp HC, Huber W \& Scheib K. Beta-endorphin and adrenocorticotrophin after incremental exercise and marathon running - female responses. European Journal of Applied Physiology and Occupational Physiology 199672 417-424.

6 Cook NJ, Read GF, Walker RF, Harris B \& Riad-Fahmy D. Changes in adrenal and testicular activity monitored by salivary sampling in males throughout marathon runs. European Journal of Applied Physiology and Occupational Physiology 198655 634-638.

7 Marinelli M, Roi GS, Giacometti M, Bonini P \& Banfi G. Cortisol, testosterone, and free testosterone in athletes performing a marathon at $4000 \mathrm{~m}$ altitude. Hormone Research 199441 225-229.

8 Banfi G, Marinelli M, Roi GS, Colombini A, Pontillo M, Giacometti $\mathrm{M}$ et al. Growth hormone and insulin-like growth factor I in athletes performing a marathon at $4000 \mathrm{~m}$ of altitude. Growth Regulation $1994482-86$.

9 Koistinen HA, Tuominen JA, Ebeling P, Heiman ML, Stephens TW \& Koivisto VA. The effect of exercise on leptin concentration in healthy men and in type 1 diabetic patients. Medicine and Science in Sports and Exercise $199830805-810$.

10 Leal-Cerro A, Garcia-Luna PP, Astorga R, Parejo J, Peino R, Dieguez C et al. Serum leptin levels in male marathon athletes before and after the marathon run. Journal of Clinical Endocrinology and Metabolism $1998 \mathbf{8 3} 2376-2379$.

11 Altenkirch HU, Gerzer R, Kirsch KA, Weil J, Heyduck B, Schultes I et al. Effect of prolonged physical exercise on fluid regulating hormones. European Journal of Applied Physiology and Occupational Physiology $199061209-213$.

12 Herrmann M, Scharhag J, Miclea M, Urhausen A, Herrmann W \& Kindermann W. Post-race kinetics of cardiac troponin T and I and $\mathrm{N}$-terminal pro-brain natriuretic peptide in marathon runners. Clinical Chemistry $2003 \mathbf{4 9} 831-834$.

13 Siegel AJ, Lewandrowski EL, Chun KY, Sholar MB, Fischman AJ \& Lewandrowski KB. Changes in cardiac markers including B-natriuretic peptide in runners after the Boston marathon. American Journal of Cardiology $2001 \mathbf{8 8} 920-923$.

14 Marin-Grez M. Fleming JT \& Steinhausen M. Atrial natriuretic peptide causes pre-glomerular vasodilatation and post-glomerular vasoconstriction in rat kidney. Nature $1986 \mathbf{3 2 4} 473-476$.

15 Atlas SA \& Maack T. Effects of atrial natriuretic factor on the kidney and the renin-angiotensin-aldosterone system. Endocrinology and Metabolism Clinics of North America $1987 \quad 16$ $107-143$.

16 Tonolo G, Richards AM, Manunta P, Troffa C, Pazzola A, Madeddu P et al. Low-dose infusion of atrial natriuretic factor in mild essential hypertension. Circulation 198980 893-902.

17 Allen MJ, Gilmour SM, Singer M \& Bennett ED. Effects of atrial natriuretic peptide on systemic haemodynamics and cardiac function in normal man. Cardiovascular Research 198923 $70-75$.

18 Richards AM, McDonald D, Fitzpatrick MA, Nicholls MG, Espiner EA, Ikram $\mathrm{H}$ et al. Atrial natriuretic hormone has biological effects in man at physiological plasma concentrations. Journal of Clinical Endocrinology and Metabolism $1988 \mathbf{6 7}$ 1134-1139.

19 Ziegler S, Niessner A, Slany J, Muller MM, Heinschink A, Billensteiner E et al. Muscle cell proteins are selectively released into the blood stream by marathon running. Acta Medica Austriaca 200330 55-58.

20 Nicholson S, Richards M, Espiner E, Nicholls G \& Yandle T. Atrial and brain natriuretic peptide response to exercise in patients with ischaemic heart disease. Clinical and Experimental Pharmacology and Physiology 199320 535-540.

21 Ohba H, Takada H, Musha H, Nagashima J, Mori N, Awaya T et al. Effects of prolonged strenuous exercise on plasma levels of atrial natriuretic peptide and brain natriuretic peptide in healthy men. American Heart Journal $2001141751-758$.
22 Edwards BS, Zimmerman RS, Schwab TR, Heublein DM \& Burnett JC Jr. Atrial stretch, not pressure, is the principal determinant controlling the acute release of atrial natriuretic factor. Circulation Research 198862 191-195.

23 de Lemos JA, McGuire DK \& Drazner MH. B-type natriuretic peptide in cardiovascular disease. Lancet $2003 \mathbf{3 6 2} 316-322$.

24 Barletta G, Stefani L, Del Bene R, Fronzaroli C, Vecchiarino S, Lazzeri $\mathrm{C}$ et al. Effects of exercise on natriuretic peptides and cardiac function in man. International Journal of Cardiology 199865 217-225.

25 Furukawa K, Kitamura H, Nishida K, Yamada C, Niki S, Sugihara $\mathrm{H}$ et al. Simultaneous changes of left ventricular and left atrial size and function in normal subjects during exercise. Japanese Heart Journal 198425 487-497.

26 Sheldahl LM, Tristani FE, Connelly TP, Levandoski SG, Skelton MM \& Cowley AW Jr. Fluid-regulating hormones during exercise when central blood volume is increased by water immersion. American Journal of Physiology 1992262 R779-R785.

27 Naimark B, Axelsson J, Sigurdsson SB \& Stephens NL. Echocardiographic indices and their relationship to the blood pressure response to ergometric exercise in apparently healthy men. Canadian Journal of Cardiology 19917 131-137.

28 Morimoto A, Nishikimi T, Takaki H, Okano Y, Matsuoka H, Takishita $\mathrm{S}$ et al. Effect of exercise on plasma adrenomedullin and natriuretic peptide levels in myocardial infarction. Clinical and Experimental Pharmacology and Physiology $1997 \quad 24$ 315-320.

29 Douglas PS, O'Toole ML, Hiller WD \& Reichek N. Different effects of prolonged exercise on the right and left ventricles. Journal of The American College of Cardiology 199015 64-69.

30 Nose H, Takamata A, Mack GW, Kawabata T, Oda Y, Hashimoto S et al. Right atrial pressure and ANP release during prolonged exercise in a hot environment. Journal of Applied Physiology $1994761882-1887$.

31 Ketelhut R, Losem CJ \& Messerli FH. Is a decrease in arterial pressure during long-term aerobic exercise caused by a fall in cardiac pump function? American Heart Journal 1994127 567-571.

32 Riddervold F, Smiseth OA, Hall C, Groves G \& Risoe C. Rateinduced increase in plasma atrial natriuretic factor can occur independently of changes in atrial wall stretch. American Journal of Physiology $1991260 \mathrm{H} 1953-\mathrm{H} 1958$.

33 Bruneau BG, Piazza LA \& de Bold AJ. BNP gene expression is specifically modulated by stretch and ET-1 in a new model of isolated rat atria. American Journal of Physiology 1997273 H2678-H2686.

34 Freund BJ, Claybaugh JR, Hashiro GM, Buono M \& Chrisney S. Exaggerated ANF response to exercise in middle-aged vs. young runners. Journal of Applied Physiology 199069 1607-1614.

35 Pastene J, Germain M, Allevard AM, Gharib C \& Lacour JR. Water balance during and after marathon running. European Journal of Applied Physiology and Occupational Physiology 1996 73 49-55.

36 Maeda S, Miyauchi T, Iemitsu M, Tanabe T, Irukayama-Tomobe Y, Goto K et al. Involvement of endogenous endothelin-1 in exerciseinduced redistribution of tissue blood flow: an endothelin receptor antagonist reduces the redistribution. Circulation $2002 \mathbf{1 0 6}$ $2188-2193$.

37 Gerth J, Ott U, Funfstuck R, Bartsch R, Keil E, Schubert K et al. The effects of prolonged physical exercise on renal function, electrolyte balance and muscle cell breakdown. Clinical Nephrology $200257425-431$.

38 Zhang Y \& Kaufman S. Effect of age on stretch-induced secretion of atrial natriuretic factor. Canadian Journal of Physiology and Pharmacology $1996 \mathbf{7 4} 132-136$.

39 Poveda JJ, Berrazueta JR, Ochoteco A, Montalban C, GarciaUnzueta MT, Fernandez C et al. Age-related responses of vasoactive factors during acute exercise. Hormone and Metabolic Research $199830668-672$.

40 Friedl W, Mair J, Pichler M, Paulweber B, Sandhofer F \& Puschendorf B. Insertion/deletion polymorphism in the 
angiotensin-converting enzyme gene is associated with atrial natriuretic peptide activity after exercise. Clinica Chimica Acta 1998274 199-211.

41 Nelson PB, Ellis D, Fu F, Bloom MD \& O'Malley J. Fluid and electrolyte balance during a cool weather marathon. American Journal of Sports Medicine 198917 770-772.

42 Grant SM, Green HJ, Phillips SM, Enns DL \& Sutton JR. Fluid and electrolyte hormonal responses to exercise and acute plasma volume expansion. Journal of Applied Physiology $1996 \mathbf{8 1}$ 2386-2392.

43 Follenius M, Candas V, Bothorel B \& Brandenberger G. Effect of rehydration on atrial natriuretic peptide release during exercise in the heat. Journal of Applied Physiology $1989662516-2521$.

44 Mudambo KS, Coutie W \& Rennie MJ. Plasma arginine vasopressin, atrial natriuretic peptide and brain natriuretic peptide responses to long-term field training in the heat: effects of fluid ingestion and acclimatization. European Journal of Applied Physiology and Occupational Physiology 199775 219-225.

45 Therminarias A, Flore P, Oddou-Chirpaz MF, Gharib C \& Gauquelin G. Hormonal responses to exercise during moderate cold exposure in young vs. middle-age subjects. Journal of Applied Physiology 199273 1564-1571.

46 McConell GK, Burge CM, Skinner SL \& Hargreaves M. Influence of ingested fluid volume on physiological responses during prolonged exercise. Acta Psychiatrica Scandinavica $1997 \mathbf{1 6 0}$ 149-156.

47 De Paoli Vitali E, Malacarne F, Vedovato M, Cavallini R, Bagni B, Nunzi L et al. Atrial natriuretic peptide and urinary sodium balance during physical exercise. Nephron 199157 $60-63$.

48 Freund BJ, Wade CE \& Claybaugh JR. Effects of exercise on atrial natriuretic factor. Release mechanisms and implications for fluid homeostasis. Sports Medicine 19886 364-377.

49 Newmark ST, Himathongkam T, Martin RP, Cooper KH \& Rose LI. Adrenocortical response to marathon running. Journal of Clinical Endocrinology and Metabolism 197642 393-394.

50 Mandalaki T, Dessypris A, Louizou C, Panayotopoulou C \& Dimitriadou C. Marathon run III: effects on coagulation, fibrinolysis, platelet aggregation and serum cortisol levels. A 3-year study. Thrombosis and Haemostasis 1980 43 49-52.
51 Rocker L, Kirsch KA, Heyduck B \& Altenkirch HU. Influence of prolonged physical exercise on plasma volume, plasma proteins, electrolytes, and fluid-regulating hormones. International Journal of Sports Medicine 198910 270-274.

52 Melin B, Koulmann N, Jimenez C, Savourey G, Launay JC, CottetEmard JM et al. Comparison of passive heat or exercise-induced dehydration on renal water and electrolyte excretion: the hormonal involvement. European Journal of Applied Physiology 200185 250-258.

53 Nagashima K, Nose H, Yoshida T, Kawabata T, Oda Y, Yorimoto A et al. Relationship between atrial natriuretic peptide and plasma volume during graded exercise with water immersion. Journal of Applied Physiology $1995 \mathbf{7 8}$ 217-224.

54 Spreca A, Simonetti S \& Rambotti MG. Atrial natriuretic peptide and guanylin-activated guanylate cyclase isoforms in human sweat glands. Histochemical Journal 200032 725-731.

55 Sengenes C, Berlan M, De Glisezinski I, Lafontan M \& Galitzky J. Natriuretic peptides: a new lipolytic pathway in human adipocytes. FASEB Journal $2000 \mathbf{1 4} 1345-1351$.

56 Sengenes C, Stich V, Berlan M, Hejnova J, Lafontan M, Pariskova Z et al. Increased lipolysis in adipose tissue and lipid mobilization to natriuretic peptides during low-calorie diet in obese women. International Journal of Obesity and Related Metabolic Disorders 200226 $24-32$.

57 Galitzky J, Sengenes C, Thalamas C, Marques MA, Senard JM, Lafontan $\mathrm{M}$ et al. The lipid-mobilizing effect of atrial natriuretic peptide is unrelated to sympathetic nervous system activation or obesity in young men. Journal of Lipid Research 200142 536-544.

58 Callow M, Morton A \& Guppy M. Marathon fatigue: the role of plasma fatty acids, muscle glycogen and blood glucose. European Journal of Applied Physiology and Occupational Physiology 1986 55 654-661.

Received 19 March 2003

Accepted 5 September 2003 